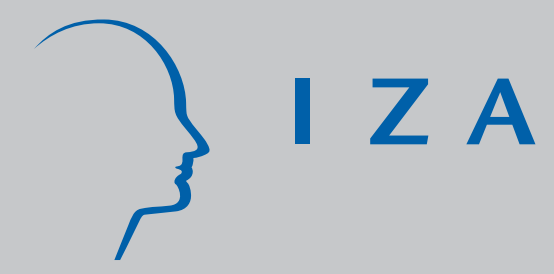

IZA DP No. 1817

Are US Wages Really Determined by

European Labor-Market Institutions?

Jürgen Meckl

October 2005 


\title{
Are US Wages Really Determined by European Labor-Market Institutions?
}

\author{
Jürgen Meckl \\ University of Giessen \\ and IZA Bonn
}

\section{Discussion Paper No. 1817 \\ October 2005}

\author{
IZA \\ P.O. Box 7240 \\ 53072 Bonn \\ Germany \\ Phone: +49-228-3894-0 \\ Fax: +49-228-3894-180 \\ Email: iza@iza.org
}

\begin{abstract}
Any opinions expressed here are those of the author(s) and not those of the institute. Research disseminated by IZA may include views on policy, but the institute itself takes no institutional policy positions.

The Institute for the Study of Labor (IZA) in Bonn is a local and virtual international research center and a place of communication between science, politics and business. IZA is an independent nonprofit company supported by Deutsche Post World Net. The center is associated with the University of Bonn and offers a stimulating research environment through its research networks, research support, and visitors and doctoral programs. IZA engages in (i) original and internationally competitive research in all fields of labor economics, (ii) development of policy concepts, and (iii) dissemination of research results and concepts to the interested public.
\end{abstract}

IZA Discussion Papers often represent preliminary work and are circulated to encourage discussion. Citation of such a paper should account for its provisional character. A revised version may be available directly from the author. 
IZA Discussion Paper No. 1817

October 2005

\section{ABSTRACT}

\section{Are US Wages Really Determined by European Labor-Market Institutions?}

This paper integrates institutionally determined wage rigidities into an otherwise standard Heckscher-Ohlin model of international trade. It accounts for differences in individual productivities and their implications for individual wage incomes and demand for education. Although preserving the factor-price-equalization property of the global equilibrium approach, the model does not support the view expressed by Davis (1998) that global equilibrium links insulate the US labor market from exogenous shocks. It provides a foundation of the derived from comparative studies that do not consistently account for the global general equilibrium links.

JEL Classification: F11, J31

Keywords: wage rigidities, international trade, education, skill-specific unemployment

Corresponding author:

Jürgen Meckl

University of Giessen

Department of Economics

VWL III

35394 Giessen

Germany

Email: juergen.meckl@wirtschaft.uni-giessen.de

\footnotetext{
* I am grateful to Max Albert, Benjamin Weigert, and two anonymous referees for helpful suggestions and comments on an earlier version of this paper.
} 


\section{Introduction}

In his much discussed "two sides of the same coin" hypothesis, Krugman (1995) attributes the contrasting labor-market experience in America and Europe to institutional differences. When faced with common exogenous shocks that raise the relative labor demand in favor of skilled labor, countries with flexible wage rates (America) should experience a rise in wage inequality, while wage inequality should rise considerable less in countries with wage rigidities (Europe) at cost of increased unskilled unemployment. ${ }^{1}$ Although Krugman's argument is, in principal, based on a general-equilibrium model of international trade, the classical Heckscher-Ohlin (HO) model, Davis (1998) challenges this approach as inconsistent with a global general-equilibrium approach. He argues that comparative studies based on separate applications of the general-equilibrium framework to different regimes of wage flexibility ignore the factor-price equalization (FPE) property that applies in a global equilibrium context. Because of the global equilibrium's FPE property, an exogenously given minimum wage in one part of the trading world ties down all prices for goods and factors all over the world and thus implies real wage rigidity for all countries producing a common set of goods. The commitment of European labor-market institutions to high wages then fully protects competitive American labor markets both against global exogenous shocks and against US-specific labor-supply shocks (like, e.g. immigration from Mexico). The link between national factor markets established by integrated world markets for goods thus generates quite counterintuitive results that are rather contrary to those from comparative studies.

The present paper develops a model that integrates institutionally set minimum wages into a global HO type model without generating Davis' counterintuitive results although it preserves the global-equilibrium FPE properties. ${ }^{2}$ It extends Davis' approach by accounting for individuals with differences in produc-

\footnotetext{
${ }^{1}$ Of course, Krugman's argument is a bit more differentiated. Wage inequality increased considerably in the US and the UK, whereas we observe more effects on unemployment in continental European economies. For sake of simplicity, however, we stick to the stylized America-Europe dichotomy.

${ }^{2}$ Other authors (cf., e.g., Atkinson (2001) or Oslington (2002)) criticize Davis' approach because it implies FPE. They suggest alternative solutions to integrate unemployment in a HO-type model that dispense with FPE. In contrast, the present approach preserves the FPE property while at the same time confirming the results from comparative cross country studies.
} 
tivities both within and between different skill groups of labor. This generates differences in individual demand for education and endogenizes the relative labor supply. ${ }^{3}$ As long as workers are rewarded according to their individual productivities, this heterogeneity also disentangles the effective wage (the firms' costs per unit of effective labor input) and the hourly wage (the wage per physical unit of labor). With minimum-wage legislation referring to the hourly wage (since this is the only wage that can be fixed), an exogenously determined wage floor does not tie down all prices. As a result, the present model preserves the results from the standard HO model in a qualitative sense, and it extends them for unemployment effects and endogenous adjustment of relative skill supplies.

The paper proceeds as follows. Section 2 recapitulates the central argument of Davis' model which will be called "insulation hypothesis". Section 3 analyzes the effect of global market integration in a model with endogenous educational decisions of heterogeneous agents. The model is applied to analyze the effect of immigration in section 4 . Section 5 concludes.

\section{Davis' Insulation Hypothesis}

Davis considers two countries - America and Europe - sharing identical constantreturns-to-scale production technologies. Each country produces two goods $(X$ and $Y$ ) that are freely traded. Production uses two types of labor inputs, skilled and unskilled labor. Both factors assumed to be indispensable in production. Factor supplies are exogenously given in each country. The key difference between America and Europe is in terms of labor-market flexibility. Whereas the US market for unskilled labor is characterized by perfect wage flexibility, the unskilled in Europe are due to wage rigidities (caused by, e.g., unions, explicit minimum wages, or social security systems). The market for skilled labor is assumed to be perfectly competitive in both countries. Finally, consumer preferences are assumed to be homothetic and identical in both countries, with both goods being essential in consumption.

The basic argument can be stated by looking at the production side of an

\footnotetext{
${ }^{3}$ Davis and Reeve (2002) also extend the Davis (1998) framework by endogenizing the choice of education. However, since they do not account for within-group worker heterogeneity, wage rigidities still determine all prices as long as the FPE property prevails.
} 
economy. Assume that, at any common factor price ratio, good $X$ is skill intensive relative to $Y$. Denote the wage of unskilled labor by $w$, the wage of skilled labor by $r$, and goods prices by $p_{X}$ and $p_{Y}$. Competitive cost conditions then ensure that for each active sector price equals unit costs:

$$
p_{X}=c_{X}(w, r), \quad p_{Y}=c_{Y}(w, r) .
$$

With fully flexible wages and a fully diversified production structure, the zeroprofit conditions (1) determine factor prices $(w, r)$ solely as a function of the goods' prices $\left(p_{X}, p_{Y}\right)$.

With wage rigidities, however, the path of determination is different. Given our assumption of homothetic consumer preferences, the unskilled workers' real wage is $w / \tilde{e}\left(p_{X}, p_{Y}\right)$, where the consumer price index used to deflate the nominal wage rate is given by the unit utility expenditure function $\tilde{e}\left(p_{X}, p_{Y}\right) .{ }^{4}$ Normalizing consumer prices according to $p_{X} \equiv p$ and $p_{Y} \equiv 1$, we can write that real wage as $z=w / e(p)$, where $e(p) \equiv \tilde{e}(p, 1)$. The zero-profit conditions then read

$$
p=c_{X}(z e(p), r), \quad 1=c_{Y}(z e(p), r) .
$$

For competitive firms in both sectors to pay a minimum wage $z$, this wage rate must be supported by an appropriate goods price $\bar{p}$. Otherwise factor payments either exceed revenues in the labor-intensive sector for any positive output $Y>0$ (in the case of $p>\bar{p}$ ), or the minimum-wage rate is not a binding constraint (in the case of $p<\bar{p}$ ). A global equilibrium featuring (i) diversified production in both America and Europe and (ii) a binding minimum wage in Europe thus implies that the terms of trade are uniquely determined by Europe's minimum wage. With perfectly competitive US labor markets, American wages are then also determined by Europe's minimum wage rate. The FPE property of the diversified global equilibrium implies that American wages are fully determined by European labor-market institutions.

FPE in the presence of an exogenously given minimum wage rate in one part of the world implies that this minimum wage determines all prices for goods and

\footnotetext{
${ }^{4}$ In principle, it is not necessary to distinguish producers' real wages and consumers' real wage in the present context. This follows because fixing one relative price and assuming a diversified production structure ties down all relative prices. In next section's model, however, setting a real minimum wage does not tie down all relative prices. In order to ensure consistency of the exposition, we assume that minimum-wage setting applies to the consumers' real wage throughout.
} 
factors all over the world. Real wage rigidity in Europe actually implies real wage rigidity for all countries in the world producing a common set of goods. Adjustment to exogenous shocks (such as exogenous labor supply shocks or integration of newly industrialized countries into world markets) can then be accomplished solely by appropriate adjustments of production quantities that are consistent with fixed prices. The reason is that to support a given minimum wage $\bar{w}$ under full diversification, the unique equilibrium price is $\bar{p}$. With homothetic consumer preferences, any exogenous shock in the relative supply of goods on world markets has to be exactly compensated by sectoral adjustment in Europe in order to support $\bar{p}$. The sole degree of freedom allowing for the required sectoral adjustments is the (un)employment of unskilled labor. The commitment of European labor-market institutions to high wages wholly insulates competitive American labor markets both from global exogenous shocks and - even more surprisingalso from US-specific labor-supply shocks (e.g. immigration from Mexico) as long as (i) the minimum wage is a binding constraint in Europe both before and after the shock and (ii) Europe and the US remain fully diversified after the shock. ${ }^{5}$

\section{The Model}

\subsection{Heterogeneous Labor and Effective Wages}

The present approach reconciles the common view on wage determination and the global general-equilibrium analysis. It develops a model that allows for integration of institutionally caused wage rigidities into an otherwise standard HO-type model of international trade that does not generate the implausible results about international wage determination or cross-country specialization patterns of the Davis model. ${ }^{6}$ The basic difference is that the present model allows for heterogeneous labor and its effect on individual wage incomes. We start from the observation emphasized in the empirical labor-market literature that individual

\footnotetext{
${ }^{5}$ I suspect that at least most labor economists would disagree with Davis' results. For example, Borjas, Freeman and Katz (1997: 62) find that immigration into the US during 198095 accounts for about a quarter to one half of the rise in wage inequality.

${ }^{6} \mathrm{Cf}$. Albert and Meckl (2001) for an efficiency-wage based approach to introduce unemployment into a general-equilibrium trade model that preserves decisive properties of the standard HO model.
} 
wage incomes differ because (i) individuals differ in their skill levels and (ii) differ in their levels of innate abilities (cf. Taber, 2001). To capture (ii), we distinguish between physical units of labor supply and effective units of labor supply. The difference between labor in physical and in effective units originates in differences in individual abilities.

The distinction between labor supply in physical units and in effective units is the main difference between our approach and that followed by Davis, who implicitly assumes that individuals are homogeneous with respect to their abilities. As a result, both effective and physical labor inputs and the effective wage (the factor price of effective labor units) and the workers' hourly wage (the wage firms pay per physical unit of labor) are also identical in Davis' model. In the present model, however, the effective wage and the hourly wage are different. Since only the hourly wage can be fixed institutionally, the effective wage is still free to adjust in the present model. But it is the effective wage that enters the firms' cost minimization problems. Denoting the effective wage for the unskilled by $w$ and for the skilled by $r$, competitive cost conditions are again given by (1). As in the standard HO model with competitive factor markets, these conditions uniquely determine the factor prices $w$ and $r$ as a function of goods' price $p$ :

$$
w=w(p), \quad r=r(p) ; \quad w^{\prime}(p)<0, r^{\prime}(p)>0 .
$$

The signs of the partial derivatives in (3) reflect our assumption that good $X$ is relatively skill intensive.

\subsection{Educational Decisions and Aggregate Factor Supplies}

We follow Meckl and Weigert (2003) in modeling individual and aggregate factor supplies. ${ }^{7}$ There is a continuum of agents. Each agent has some ability $a \in[0,1]$. The density of agents with ability $a$ is $f(a)$. The mass of the density function is normalized to 1 , that is, $\int_{0}^{1} f(a) d a=1$. The composition of labor supply is endogenously determined by decisions of individuals with different abilities. For the moment, let us dispense with any form of institutional wage rigidities.

An individual with ability $a$ can either enter the labor force as unskilled thereby supplying $(1+a)$ units of unskilled labor and earn the wage rate $w$

\footnotetext{
${ }^{7}$ In contrast to the present paper, Meckl and Weigert (2003) emphasize the impact of educational decisions on measured wage inequality in a HO-type model of a small open economy.
} 
per unit of effective labor. ${ }^{8}$ Alternatively, an individual can choose to spend a exogenously given fraction $\lambda$ of time in training to become a skilled worker. Education is assumed to raise individual abilities. For simplicity, we assume individual abilities of skilled workers to be $b a$, where $b>1$ can be interpreted as a measure of the efficiency of the educational system. Thus, a skilled worker with ability $a$ supplies $(1-\lambda)(1+b a)$ units of skilled labor and earns the wage rate $r$ per unit of effective labor. The wage income of an individual with ability $a$ then either is $(1+a) w$ as an unskilled worker, or $(1-\lambda)(1+b a) r$ as a skilled worker.

An individual chooses to become skilled iff its ability is not smaller than some threshold value $t$ determined by

$$
t(p)=\{a:(1+a) w(p)-(1+b a)(1-\lambda) r(p)=0\} .
$$

Since both skilled and unskilled labor are indispensable in production, we must focus on interior solutions $t \in(0,1)$ This requires $2 /(1+b)<(1-\lambda) \omega(p)<$ 1 , where $\omega(p) \equiv r(p) / w(p)$. Furthermore, given our assumptions about factor intensities, $t$ is a function of $p$ with $t^{\prime}(p)<0$.

Individual education decisions determine the aggregate supplies of unskilled and skilled labor $(L$ and $H)$ as functions of $p$. Factor supplies are given by

$$
L(p)=\int_{0}^{t(p)}(1+a) f(a) d a, \quad H(p)=\int_{t(p)}^{1}(1-\lambda)(1+b a) f(a) d a,
$$

with $L^{\prime}(p)<0$, and $H^{\prime}(p)>0$. As a result, relative labor supply $h(p):=$ $H(p) / L(p)$ is an increasing function of the goods price $p$. Full flexibility of factor prices then ensures that $L(p)$ and $H(p)$ are always fully employed, implying that $h(p)$ also measures relative labor employment.

Suppose now that there is an institutionally set wage floor $z$ below which the real hourly wages paid in an economy must not lie. For simplicity, we take the value of $z$ as given exogenously. Furthermore, we assume that the wage floor is sufficiently low such that minimum-wage legislation is not relevant for skilled labor. With respect to the unskilled, however, the wage floor may be binding. An unskilled worker with ability $a$ receives a real hourly wage $(1+a) w / e(p)$. Existence a real wage floor then requires

$$
\frac{(1+a) w(p)}{e(p)} \geq z .
$$

\footnotetext{
${ }^{8}$ Note that we implicitly normalize working hours to unity.
} 
Given that $w^{\prime}(p)<0$ and $e^{\prime}(p)>0$, the constraint (6) is not binding for $p \leq p_{0}$, where $p_{0}$ solves

$$
w(p)=z e(p) .
$$

At prices $p \leq p_{0}$, all unskilled have sufficient productivity to earn the minimum hourly wage at the respective real return to effective unskilled labor $w(p) / e(p)$. With a binding wage floor, however, there are individuals with a productivity that is too low to guarantee them a real hourly wage of $z$ at the real return to effective unskilled labor $w(p) / e(p)$. Consequently, these individuals are not employed by any of the firms. The threshold ability $\tau$ to become employed is then determined by

$$
\tau(p, z)=\{a:(1+a) w(p)=z e(p)\}
$$

Our assumptions about factor intensities imply that $\tau$ is increasing both in $p$ and in $z$.

With wage rigidities, the aggregate unemployment rate amounts to

$$
u(p, z)=\int_{0}^{\tau(p, z)} f(a) d a .
$$

The unemployment rate rises with $z$ and-due to our assumptions about factor intensities - is also increasing in $p$. Aggregate employment of unskilled labor is

$$
\tilde{L}(p, z)=\int_{\tau(p, z)}^{t(p)}(1+a) f(a) d a,
$$

with $\partial \tilde{L}(p, z) / \partial p<0$, and $\partial \tilde{L}(p, z) / \partial z<0$. Consequently, relative labor employment $\tilde{h}(p, z):=H(p) / \tilde{L}(p, z)$ is increasing in both $p$ and $z$.

\subsection{Equilibrium Prices and Unemployment}

Consider a world consisting of two countries with free trade in goods and no international factor mobility. Both countries are alike in every respect except for labor-market institutions. Labor markets in one country - Europe - are characterized by institutionally fixed wage floors. Labor markets in the other countryAmerica - are fully competitive. From our analysis in the preceding subsection we get that, for any goods price compatible with (weak) diversification and a binding 
wage floor, incentives to acquire education are identical in both countries. ${ }^{9}$ This implies identical supplies of both types of labor in both countries. With no wage rigidities in America, the supply of unskilled labor is fully employed there. Due to the wage floor, however, Europe's employment of unskilled is less than America's. Consequently, Europe's relative employment of skilled labor exceeds that of America, while aggregate income in Europe is less than in America because of unemployment.

\section{Please insert figure 1 here!}

Now we analyze the global equilibrium by applying the graphical technique shown in figure 1 . The downward sloping curve $C C$ shows the relative demand for goods as a function of $p$ that is common to Europe and America (reflecting our assumptions about consumer preferences). The upward sloping curve $A A$ depicts the supply of $X$ relative to $Y$ of the US economy. In contrast to the standard HO model, an increase in $p$ raises relative supply by two effects. In addition to the usual sectoral restructuring in favor of $X$ at given factor supplies, the increase in the relative factor price $\omega$ additionally lowers the threshold for acquiring education. Thus, the relative supply of skilled labor rises reinforcing sectoral adjustments by a standard Rybcynski effect. In Europe that second effect is stronger than in the US since an increase in $\omega$ additionally raises the threshold $\tau$, thus reducing the aggregate employment of unskilled labor even by more. As a result, relative employment of skilled labor exceeds relative employment in the US at any price that gives rise to a binding minimum wage. For all prices $p>p_{0}$, Europe's relative supply curve lies to the right of America's, and its slope is less than the slope of the American relative supply curve. ${ }^{10}$

It is obvious from figure 1 that equilibrium autarky prices (determined by the intersection of national relative demand and relative supply curves as $p^{A}$ and $p^{E}$, respectively) differ and hence international differences in institutionally set

\footnotetext{
${ }^{9}$ This implicitly assumes that the parameters $b$ and $\lambda$ are identical for both countries.

${ }^{10}$ In contrast, Davis approach implies that Europe's relative supply becomes infinitely elastic at $p=\bar{p}$ (implying a flat segment in Europe's import demand curve). All his relatively drastic results are caused by this infinite elasticity.
} 
wage floors give rise to trade. The opening up of trade implies a striking contrast between labor markets in Europe and in America. Suppose that $p^{*}$ is the price in the free-trade equilibrium. In Europe, the rise in $p$ reduces $w$ and therefore drives up unemployment (for a given $z$ ). In America, the decline in $p$ raises $w$. In principal, these results are in line with that from Davis' analysis: opening up trade between Europe and America raises both American wages and European unemployment rates. The mechanism driving these results, however, is completely different. In our model, it is the change in goods prices and the resulting changes in factor prices that alter production structures, educational decisions, and the impact of wage floors on unemployment. Basically, our mechanism is similar to the well-known adjustment mechanism from the standard full-employment HO model. The only difference with respect to the full employment version is that quantitative reactions additionally account for (i) endogenous labor supply adjustments that are generated by a change in educational decisions of individuals and (ii) employment adjustments from the change in the unemployment theshold. Eventually, our results provide a sound foundation for the arguments made in the comparative cross-country studies that have been criticized by Davis.

\section{Shocks from the South: Implications for Eu- rope and America}

The insulation thesis stating that exogenous changes in world factor supplies do neither affect American wages nor the aggregate global production quantities is the most controversial implication of European wage institutions in Davis' analysis. The present model shows that the general-equilibrium link does not necessarily imply that the part of the world with wage rigidities has to bear the complete burden of adjustment to exogenous shocks.

Consider immigration of unskilled labor from third countries into the US. Suppose further that immigrants cannot acquire education in the US. ${ }^{11}$ Since the decisions about acquiring education depend on the goods price, the non-migrants' investment incentives at any given $p$ do not change after immigration. Immigration, however, reduces the relative supply of skilled labor for each $p$, thus raising

\footnotetext{
${ }^{11}$ Alternatively, one can analyze immigration of individuals at the bottom end of the ability scale.
} 
the difference in effective relative labor supplies between America and Europe. This change in relative employment alters the US relative supply of goods in favor of $Y$ at any admissible price. In terms of figure 1, immigration shifts the American relative supply curve $A A$ to the left. Consequently, the new goods price supporting global equilibrium is some $p^{\prime}>p^{*}$. Thus, we arrive at the results prospected by empirical labor-market studies on the effect of immigration: Immigration of unskilled labor into the US reduces the wage income of the unskilled there while driving up the incentives to invest in education within the native population. In Europe, the effects are identical with respect to wage incomes of the unskilled, and about educational incentives. Additionally, unskilled unemployment rises.

\section{Conclusions}

This paper has shown that minimum-wage-income constraints can be introduced into the classical Heckscher-Ohlin framework of international trade without altering the results derived form the standard full-employment version of that model in a fundamental way. Contrary to what is expected from Davis' (1998) analysis of minimum wages in a HO-type model, wage rigidities in Europe do not insulate the flexible--wage economies like America from exogenous shocks by shifting the complete burden of quantity adjustments to European labor markets. In our model, each exogenous shock renders price adjustments that generate adjustments in national production structures for all trading partners. Nevertheless, European unemployment does indeed prop up American wages. This is a consequence of national labor markets being linked by integrated goods markets in a global economy. However, global general equilibrium effects do not equalize wage incomes in countries with completely different labor-market institutions. Our results and the mechanisms driving them are more in line with that derived from comparative studies (cf. Krugman, 1995), thus providing a consistent common framework for these results.

Our model also overcomes another problematic implication of Davis' approach concerning specialization patterns within European economies. In European countries sharing wage rigidities, minimum wages are by no means identical. But if minimum-wage rates differ between European economies, Davis' HO-type framework either implies that only the highest minimum wage is actually bind- 
ing (with no unemployment in all other European economies) or that complete specialization of production on the skill-intensive good occurs in all economies with binding minimum-wage rates ${ }^{12}$ but the diversified economy with the lowest minimum wage. This implication, however, is clearly contrary to fact. Only if one allows for specific technological differences within European countries it is theoretically possible that different minimum-wage rates are supported by an identical goods price $\bar{p}$ and diversification occurs in all countries. But this is a knife-edge case of minor practical importance. Since in our model the minimumwage-income constraints do not completely determine factor prices, the model is compatible with diversification in all economies irrespective of the specific value of the minimum wage income.

\footnotetext{
${ }^{12}$ This corresponds to the minimum--wage induced specialization patterns in a small-openeconomy version of the HO model discussed by Neary (1985).
} 


\section{References}

Albert, M., Meckl, J. (2001): "Wage Differentials, Factor Intensities, and Unemployment: A Heckscher-Ohlin Trade Model," German Economic Review 2, 287-301.

Atkinson, A.B. (2001): "A Critique on the Transatlantic Consensus on Rising Income Inequality," World Economy 24, 433-452.

Borjas, G.J., Freeman, R.B., Katz, L.F. (1997): "How much do Immigration and Trade Affect Labor Market Outcomes?" Brookings Papers on Economic Activity 7, 1-90.

Davis, D.R. (1998): "Does European Unemployment Prop Up American Wages? National Labor Markets and Global Trade," American Economic Review 88, 478-494.

Davis, D.R., Reeve, T.A. (2002): "Human Capital, Unemployment, and Relative Wages in a Global Economy,", in: Greenaway D. et al. (eds.), Trade, Investment, Migration and Labour Market Adjustment, Houndmills/UK: Palgrave MacMillan, 7-27.

Krugman, P.R. (1995): "Growing World Trade: Causes and Consequences," Brookings Papers on Economic Activity, 327-377.

Meckl, J., Weigert, B. (2003) "Globalization, Technical Change, and the Skill Premium: Magnification Effects from Human-Capital Investments," Journal of International Trade and Economic Development 12, 319-336.

Neary, J.P. (1985): "International Factor Mobility, Minimum Wage Rates, and Factor-Price Equalization: A Synthesis," Quarterly Journal of Economics 100, 551-570.

Oslington, P. (2002): "Trade, Wages, and Unemployment in the Presence of Hiring and Firing Costs," The Economic Record 78, 195-206.

Taber, C.R. (2001): "The Rising College Premium in the Eighties: Return to College or Return to Unobserved Ability?" Review of Economic Studies, 68, 665-691. 


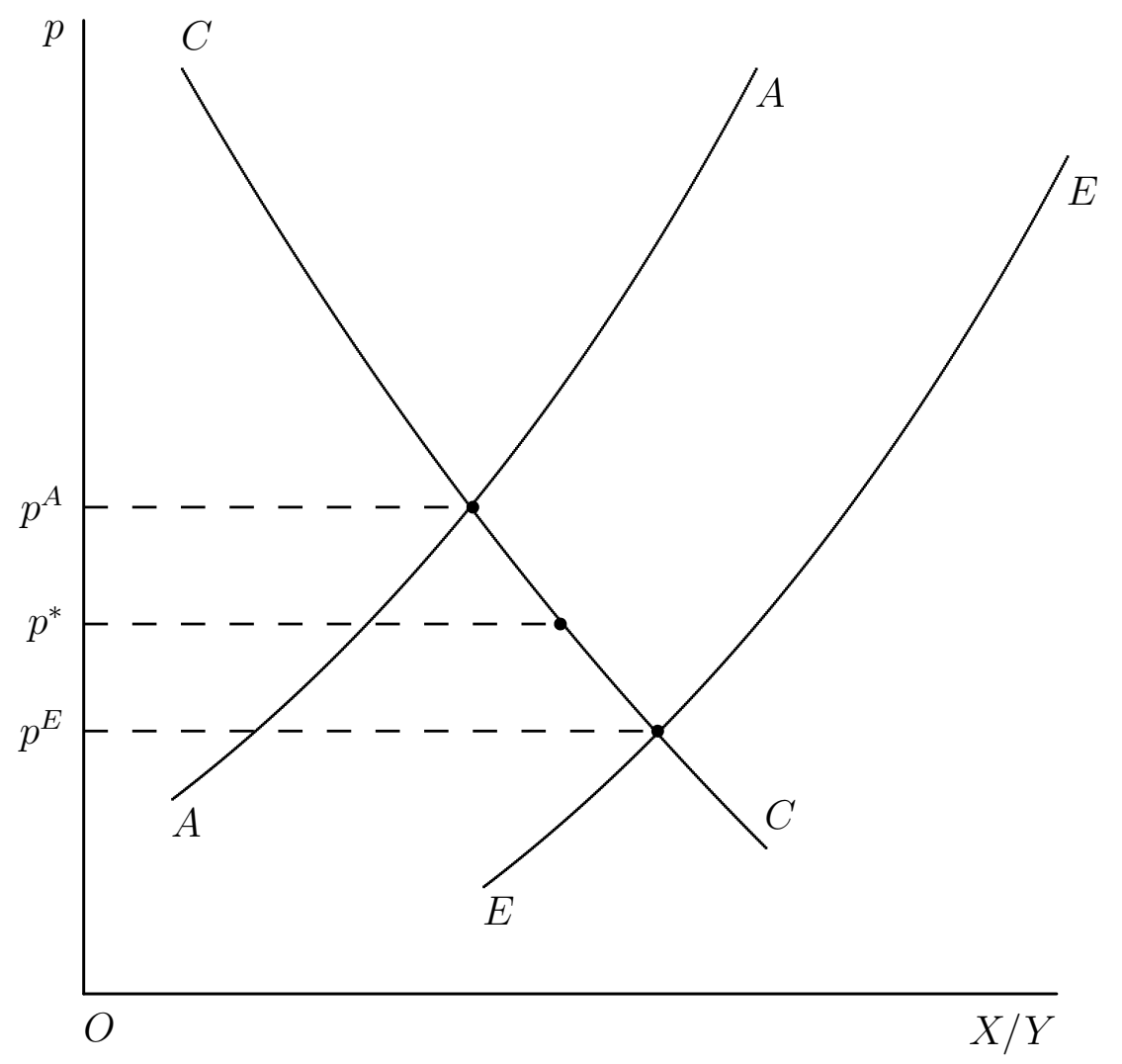

Figure 1: Determination of autarky prices 